solution was closely similar to that of riboflavin. The silver salt of the prosthetic group is insoluble, and notatin is therefore probably a dinucleotide.

Notatin only exerts its anti-bacterial activity under certain well-defined conditions, but under these conditions it is a very powerful bactericide. The conditions are :

(1) presence of oxygen ;

(2) presence of glucose ;

(3) absence of appreciable amounts of catalase.

Our best preparations completely inhibit the growth of Staphylococcus aureus in dilutions as great as 1 part in $1,000,000,000$. They are also active in very high dilutions against other Gram-positive and Gram-negative organisms including Strep. hoemolyticus, Strep. pneumonia, Bact. typhosum, Bact. paratyphosum $A$ and $B$, Bact. typhi-murium, $V$. cholerce, Bact. anthracis and Proteus vulgaris.

It has been found that in the presence of notatin, glucose is converted by oxygen to gluconic acid with simultaneous production of hydrogen peroxide. Quantitative experiments indicate that the oxidation may be represented by the equation

$$
\text { R.CHO }+\mathrm{H}_{2} \mathrm{O}+\mathrm{O}_{2} \rightarrow \mathrm{R} . \mathrm{COOH}+\mathrm{H}_{2} \mathrm{O}_{2} \text {, }
$$

although there is a deficiency of hydrogen peroxide when notatin is contaminated with catalase. The whole behaviour of notatin is thus consistent with the view that it is an enzyme similar to, but much more potent than, the glucose oxidase obtained by Müller" from Aspergillus niger mycelium and further examined by Franke and his collaborators ${ }^{8}$, who consider it better described as a glucose aerodehydrogenase.

In vivo experiments are in progress and will be reported at a later date; there is evidence of a therapeutic effect with exceedingly minute doses of notatin.

In a recent publication ${ }^{9}$ Kocholaty mentions "penatin", a newly discovered anti-bacterial substance produced by Penicillium notatum Westling, which differs from penicillin. The chemical and bacteriological results given in his communication are insufficient to show whether penatin is identical with notatin.

The work described above was carried out under the ægis of the Therapeutic Research Corporation of Great Britain Ltd. A more detailed account of the investigation will be published in due course.
C. E. Coulthard.
R. Michaelis.
W. F. SHORT.
G. Sykes.

Boots Pure Drug Co., Ltd.

G. E. H. Skrtmshire. A. F. B. Standfast.

The British Drug Houses Ltd.

J. H. Birkinshaw.

H. Raistrick.

London School of Hygiene

and Tropical Medicine.

Nov. 14.

${ }^{1}$ British Patent Application No. 13242 of October 14, 1941 : Boots Pure Drug Co., Ltd., C. E. Coulthard, R. Michaelis and W. F. Short.

2.Fleming, Brit. J. Exp. Path., 10, 226 (1929).

'Clutterbuck, Lovell and Raistrick, Biochem. J., 26, 1907 (1932).

- Chain, Florey, Gardner, Heatley, Jennings, Orr-Ewing and Sanders, Lancet, 239, 226 (1940) A'braham, Chain, Fletcher, Florey, Heatley and Jennings, ibid, 241, 177 (1941), Abraham, Chaj and Holiday, Brit. J. Exp. Path., 23, 103 (1942). Florey and Jennings, ibid., 23, 120 (1942).

s British Patent Application No. 8189 of June 15, 1942 : The British Drug Houses, Ltd., and G. E. H. Skrimshire.

- Biochem. Z., 298, 150 (1938).

'Biochem. Z., 199, 136 (1928); 205, 111 (1929). Ergebnisse der Enzymforschung, 5, 259 (1936).

Annalen, 532, 1 (1937); 541, 117 (1939).

J. Bact., 44, 142 (1942).

\section{Transformation of Benzpyrene in the Living Skin of Mice into a Compound Soluble in Dilute Alkali}

THe skin of white mice painted with benzpyrene fluoresces violet at first, but within two to four days the colour of the fluorescence changes slowly to blue. The blue persists for two to three weeks, until it cannot be distinguished from the natural bluishwhite fluorescence of the skin ${ }^{2}$. The spectrum of the violet fluorescence contains the typical groups at 427 and $455 \mathrm{~m} \mu$ of molecularly dispersed benzpyrene. The blue spectrum contains two diffused bands at about 450 and $425 \mathrm{mu}$. It is similar to, but apparently not identical with, the fluorescence spectra of ' $\mathrm{BPX}$ ', 2,3 and the orthorhombic crystalline modification of pure benzpyrene ${ }^{4}$. It is, however, different from the fluorescence spectrum of the monohydroxybenzpyrene which Chalmers and Crowfoot ${ }^{5}$ have isolated from the fæces of rats injected with benzpyrene. We have also observed this blue fluorescence in the kidney cortex, liver and lung of mice and rabbits, and in the protein fraction of the milk of lactating mice after injection of benzpyrene ${ }^{1}$.

In a new set of experiments the skins of white mice were painted with benzpyrene in acetone and the mice were killed after various periods from $\frac{1}{4} \mathrm{hr}$. to eight days. The skins were then removed, dried and extracted with cold benzene to remove the loosely attached benzpyrene. Fluorescence spectrography of the transparent skins mounted in xylol between slides showed the 'blue' bands from about six hours after painting. They increased in strength until the fourth day and then faded slowly. The dry skins of 1- to 4-day mice were treated overnight with $(a) 0.01 \mathrm{~N}$ caustic soda and $(b) 0.01 \mathrm{~N}$ hydrochloricacid.

(a) The alkaline extract fluoresced blue, while the extracted skin retained some of its fluorescence; after acidifying, the blue fluorescence could be extracted with ether and re-transferred to the aqueous phase by adding fresh alkali.

(b) The acid did not show any fluorescence due to benzpyrene, but on extracting the acid-wet skins with ether, blue fluorescence (with weak violet bands deriving from traces of unextracted molecular benzpyrene) entered the ether. The blue fluorescence could be transferred to the aqueous phase with $0.01 N$ caustic soda, and re-transferred into ether after acidifying.

It must be concluded that the blue fluorescence is due to a benzpyrene derivative which is soluble in alkali. It is produced in the painted skins, and persists over periods of several weeks.

We established by low-power microscopy in ultraviolet light that a strong blue fluorescence followed exactly the rows of the hair bulbs. This indicates that the compound is confined to the quickly proliferating cells of the Malpighian layer. It may therefore be of greater importance for the production of tumours than the original benzpyrene itself, especially because this blue-fluorescent compound persists in the skin long after the parent hydrocarbon has disappeared.
Mount Vernon Hospital,
J. C. Mottram.
Northwood, Middlesex.
F. WEIGERT. Nov. 11.

${ }^{1}$ Weigert, F. Brief reports in Chem. and Ind., p. 641 (1941) and Brit. Emp. Cancer Campaign Report, p. 90 (1941); full account in the Press.

2 Peacock, P. R., Brit. J. Exp. Path., 17, 164 (1936).

almers, F. G., Biochem. J., 32, 271 (1938).

- Weigert, F., and Mottram, J. C., NA'ruRE, 145, 895 (1940).

${ }^{5}$ Chalmers, F. G., and Crowfoot, Dorothy, Biochem. J., 35, 1270 (1941). 